\title{
Acute vascular rejection after kidney transplantation outcome and effect of different therapeutic modalitis
}

\author{
Ehab Wahba Wafa, M.D., Mohamed Ashraf Fouda, M.D., Mahmoud El Baz, M.D., Amany \\ Moustafa, M.D. and Mohamed A. Ghoneim, M.D., M.D. (Hon.)
}

Urology and Nephrology Center. Mansoura University, Egypt

\begin{abstract}
Background

Steroid resistant acutc vascular rejection (AVR) is great obstacle in successful renal transplantation (KTx). The aim of this work was to evaluate the outcome of histologically confirmed acule vascular rejection-which of occurred in severe aggressive form in 39 patients following kidney transplantation as well as to study the outcome of therapy. Thesc cases were chosen from 1000 renal allograft recipients who underwent kidncy transplantation in the period between March, 1976 and April 1997 in Urology-Nephrology Center, Mansoura, Egypt.
\end{abstract}

\section{Methods}

Statistical analysis of risk factors leading to AVR wats calried out. The outcome of different rescue therapics used for AVR as well as graft survival functions were also analyzed.

Results:

Survival analysis for grafts with AVR revealed $60 \%, 53 \%, 30 \%, 0 \%$ graft survival at $1,2,5,10 \mathrm{ys}$ respectively alter $\mathrm{T} x$.

A statistically significant difference was found in comparison to patients who only experienced aculc cellular rejection $(90 \%, 84 \%, 71 \%, 46 \%$ graft survival at $1,2,5,10$ years post- K.Tx respectively) or patients who passed without rejection in their posttransplantation follow up $(95 \%, 91.3 \%, 83.3 \%$ $65.5 \%$ graft survival at $1,2,5,10$ ys respectively).

No statistically significant difference on the overall graft survival between the different modalities of thcrapy was noted. Steroid pulses +plasma exchange were given for 14 patients with AVR, whereas ATG. $\mathrm{MAB} \pm$ plasma exchange were added to steroid resistant cases (25 patients)

Logistic regression analysis of these data showed that prior blood transfusion, donor-recipient consanguinity, retransplantation are the most significant variables related to occurrence of AVR after kidney transplantation.

At last follow up, 14 patients $(35.9 \%)$ werc living with functioning grafts, 16 patients (41\%) were living on dialysis, 5 patients died with functioning grafts $(12.8 \%)$ and 4 paticnts $(10.25 \%)$ died with failed grafts.

In conclusion: AVR remains a major obstacle for renal transplantation as it markedly impaired graft survival and responded poorly to therapy. Prior blood transfusion decreased the incidence of AVR whereas retransplantation and unrelated donation account significantly to the occurrence of AVR after renal Tx.

Key words: Acute vascular rejection; ATG; kidney transplantation; $\mathrm{MAB}$; plasma exchange 


\section{Introduction}

Early steroid resistant predominantly vascular acute rejection is a barrier to successful kidney transplantation (KTx) $[1,2]$.

This despite the sophisticated use of immunosuppressive drugs and improved understanding of cellular and humoral host responses in transplanted organs during recent years. Several reports considred early vascular rejection, occurring within 3 months after renal $T x$, as one of the most important predicting variable for both early and late graft loss [3,4]. The incidence of acute vascular rejection (AVR) after $\mathrm{K} T \mathrm{Tx}$ was reported in one series to be as high as $26 \%$ [5] and that the risk of developing vascular rejection decreased in patients using Ciclosporin (Cs), (as compared with Azathioprine), those having less HLA-DR mismatches and short duration of cold ischaemia [3]. It was also reported that previous transplantation possibly increase the incidence and severity of AVR [3]. Living unrelated transplantation was found to be attended with severe irreversible AVR, poor graft outcome as well as several medical and surgical complications [6,7].

Acute cellular rejection (ACR) usually responds well to steroids but the proper treatment of AVR is still a problem. In general, the success of treatment of vascular rejection is still poor [8].

Several therapeutic trials were conducted to evaluate the efficacy of antithymocyte polyclonal antibodies (ATG) in steroid resistant rejection (SRR) in patients treated with prednisolone and azathioprine and also in patients with $(\mathrm{Cs})[9,10]$. Successful use of ATG was reported in $70 \%$ of SRR on treatment with triple immunosuppression [11].
$\mathrm{OKT}_{3}$ (monoclonal antibodies) was found to successfully reverse acute rejection in most patients who have failed to respond to prolonged courses of high doses of steroids [12] and in many instances to ATG as well. The monoclonal antibodies (MAB) are specifically directed to the CD3 molecules on lymphocytes and consequently is expected to be a rescue therapy for $A V R[13,14]$

Plasma exchange (PE) was recognized as an important approach to therapy of SRR predominantly AVR which is refractory to conventional immunosuppression by removal of lymphocytotoxic antibodies [15]. PE has been used with success either alone [16] or in combination with ATG, steroid, OKT3 to reverse AVR $[17,18]$.

The aim of the present study was to evaluate the impact of AVR on graft survival as well as to evaluate the efficacy of different therapeutic modalities to treat biopsy proven AVR following kidney transplantation.

\section{Materials and methods}

In the period from 1976 to 1997, 1000 consecutive kidney transplantations were carried out in our Center. All received their grafts from living donors. Of these, 39 patients had suffered episodes of histologically-proven acute vascular rejection (AVR). They were 10 females, and 29 male patients with a mean age of $30.4 \pm 10.9$ ycars. Patient characteristics and the original kidney discase are summarized in tables 1,2 respectively.

Table 1. Patients demographics

\begin{tabular}{|c|c|c|c|c|c|}
\hline \multirow[t]{2}{*}{ Characteristics } & \multicolumn{2}{|c|}{ Vasculitic group ( $n=39$ patients) } & \multicolumn{2}{|c|}{ Non vasculitic group ( $1=961$ parients) } & \multirow[t]{2}{*}{$P$} \\
\hline & no & $\%$ & no & $\%$ & \\
\hline \multicolumn{6}{|l|}{ 1. Recipient age } \\
\hline$<10$ & 1 & $(2.6)$ & 22 & $(2.3)$ & \\
\hline $10-20$ & 7 & (17.9) & 138 & $(14.4)$ & 0.81 \\
\hline $21-30$ & 12 & $(30.8)$ & 355 & $(36.9)$ & \\
\hline $31-40$ & 11 & $(28.2)$ & 304 & $(31.6)$ & \\
\hline $41-50$ & 8 & $(20.5)$ & 127 & $(13.5)$ & \\
\hline $51-60$ & 0 & $(00.0)$ & 14 & $(1.5)$ & \\
\hline \multicolumn{6}{|c|}{ 2-Sex of recipients : } \\
\hline a- Male & 29 & $(74.4)$ & 703 & $(73.2)$ & 0.86 \\
\hline b-Female & 10 & $(25.6)$ & 258 & $(26.8)$ & \\
\hline \multicolumn{6}{|l|}{ 3-Age of donor } \\
\hline $21-30$ & 19 & $(48.8)$ & 423 & $(44.0)$ & \\
\hline $31-40$ & 13 & (33.3) & 295 & $(30.7)$ & \\
\hline $41-50$ & 5 & $(12.8)$ & 174 & $(18.1)$ & 0.57 \\
\hline $51-60$ & 1 & $(2.6)$ & 63 & $(6.6)$ & \\
\hline$>60$ & 1 & $(2.6)$ & 6 & $(0.6)$ & \\
\hline 4- Sex of donor & $\cdot$ & & & & \\
\hline a-Male & 25 & $(64.1)$ & 481 & $(50.1)$ & 0.08 \\
\hline b-Female & 14 & $(35.9)$ & 480 & $(49.9)$ & \\
\hline
\end{tabular}


Table 2. Original kidney discase

\begin{tabular}{|c|c|c|c|c|}
\hline \multirow[t]{2}{*}{ Diagnosis } & \multicolumn{2}{|c|}{ Vasculitic group (no=39 patients) } & \multicolumn{2}{|c|}{ Non-Vasculitic (no=961 patients) } \\
\hline & no & $\%$ & no & $\%$ \\
\hline $\begin{array}{l}\text { 1- Chronic } \\
\text { glomerulonephritis }\end{array}$ & 7 & 21.9 & 76 & 9.7 \\
\hline $\begin{array}{l}\text { 2- Chronic } \\
\text { pyelonephritis }\end{array}$ & 1 & 31 & 125 & 160 \\
\hline 3- Nephrosclerosis & 4 & 12.4 & 36 & 4.6 \\
\hline $\begin{array}{l}\text { 4- Polycysic kidney } \\
\text { disease }\end{array}$ & 2 & & 41 & $5 ?$ \\
\hline 5- Obstruclive & 2 & 0.3 & 41 & 3.2 \\
\hline $\begin{array}{l}\text { uropathy } \\
\text { 6- Hereditary }\end{array}$ & 0 & 0 & 13 & 1.7 \\
\hline nephritis & 3 & 9.4 & 24 & 3.1 \\
\hline 7- Amyloidosis & 0 & 0 & 20 & 2.6 \\
\hline P value* & & $<0.04$ & & \\
\hline End stage kidney disease & 22 & $(56.4)$ & 665 & $(69.2)$ \\
\hline
\end{tabular}

* Significant at $\mathrm{P} \leq 0.05$

\section{Immunologic variables}

The AVR group included 33 patients who had there [St transplant and in six cases it was the second. All patients received their grafts from living donors. A negative $T$ lymphocyte cross match was a prerequisite for transplantation. Seventeen patients (43.6\%) received non-specific blood transfusion prior to transplantation. Twenty-three were living related kidney transplantation whereas 16 patients received their grafts from unrelated or emotionally- related donors (table 3 ).

Table 3 Immunological variables

\begin{tabular}{|c|c|c|c|c|c|}
\hline \multirow[t]{2}{*}{ Characteristics } & \multicolumn{2}{|c|}{ Vasculitic group ( $n=39$ patients) } & \multicolumn{2}{|c|}{ Non vasculitic group ( $n=96 /$ patients) } & \multirow[t]{2}{*}{$P$} \\
\hline & no & $\%$ & no & $\%$ & \\
\hline \multicolumn{6}{|c|}{ 1- Donor/Recipien consanguinity } \\
\hline a-Related & 23 & $(58.97)$ & 780 & $(81.2)$ & \multirow[t]{2}{*}{0.0006} \\
\hline b-Unrclated & 16 & $(41.02)$ & 181 & $(10.8)$ & \\
\hline \multicolumn{6}{|l|}{ 2- Blood group } \\
\hline a-Same & 30 & (76.9) & 826 & $(86.0)$ & \multirow[t]{2}{*}{0.11} \\
\hline b-Different & 9 & (23.1) & 135 & $(14.0)$ & \\
\hline \multicolumn{6}{|l|}{ 3- HILA match } \\
\hline Zero match & 3 & $(7.7)$ & 66 & $(7.0)$ & \multirow{5}{*}{0.68} \\
\hline One malch & 8 & $(20.5)$ & 147 & $(15.6)$ & \\
\hline Two match & 22 & $(56.4)$ & 553 & $(57.5)$ & \\
\hline Three match & 6 & $(15.4)$ & 156 & $(16.5)$ & \\
\hline Four match & 0 & $(0)$ & 39 & (4.1) & \\
\hline \multicolumn{6}{|l|}{ 4- DR match } \\
\hline Zero match & 0 & & 13 & $(1.4)$ & \multirow{3}{*}{0.18} \\
\hline One match & 36 & $(92.3)$ & 920 & (95.7) & \\
\hline Two mulch & 3 & $(7.7)$ & 28 & $(2.9)$ & \\
\hline \multicolumn{6}{|c|}{ 5-Pretransplant blood transfusion } \\
\hline Non transfused & 22 & $(56.4)$ & 312 & $(24.7)$ & 0.001 \\
\hline \multicolumn{6}{|c|}{ 6-number of blood transfusion: } \\
\hline $1-3$ tines & 9 & $(52.9)$ & 281 & $(43.3)$ & \multirow{3}{*}{0.708} \\
\hline 4-5 limes & 3 & $(17.6)$ & 121 & (18.6) & \\
\hline$>5$ limes & 5 & $(29.4)$ & 247 & $(38.1)$ & \\
\hline \multicolumn{6}{|l|}{ 7- Graft received: } \\
\hline first & 33 & $(84.6)$ & 928 & $(96.6)$ & \multirow[t]{2}{*}{0.00016} \\
\hline second & 6 & $(15.4)$ & 33 & (3.4) & \\
\hline
\end{tabular}

\section{Immmunosuppression}

Over the years, different protocols of immumo- suppression were employed. These were previously published $[19,20]$ and are displayed in table 4. 
Table 4. Post-transplant factors

\begin{tabular}{|c|c|c|c|c|c|}
\hline & \multicolumn{2}{|c|}{ Vasculitic group (no=39 patiemts) } & \multicolumn{2}{|c|}{ Non-Vasculitic group (no= $=961$ patients) } & \multirow[t]{2}{*}{$P$} \\
\hline & no & $\%$ & no & $\%$ & \\
\hline \multicolumn{6}{|c|}{ |-Initial Immunosupression } \\
\hline a-Steroids+1mmuran & 10 & $(25.6)$ & 289 & $(30.1)$ & \\
\hline b-Steroid+Ciclosporin & 5 & $(12.8)$ & 167 & $(17.4)$ & 0.42 \\
\hline c-Tripple & 24 & $(61.5)$ & 505 & $(52.5)$ & \\
\hline \multicolumn{6}{|c|}{ 2-Number of acute rejections } \\
\hline $0-1$ & 21 & (53.8) & 732 & $(71.6)$ & \\
\hline$\geq 2$ & 18 & $(46.1)$ & 229 & 23.8 & 0.002 \\
\hline
\end{tabular}

\section{Diagnosis of rejection}

Acute rejection was determined according 10 commonly accepted clinical, laboratory criteria. Fine needle aspiration cytology and ultrasound guided percutaneous $(\mathrm{Pc})$ needle biopsy were carried out for patients showing deterioration of graft function and whenever acute rejection was suspected. Graft biopsies were revised according to Banff's classification [21] and severe cases of AVR (Banff grade III) were only included in this sludy. The diagnosis of AVR was made by the following findings: Intimal arteritis (endovasculitis), proliferation and swelling of endothelium with edema of the intima and/or mononuclear cell infiltration and adherence of mononuclear cells to endothelium. Fibrinoid necrosis of small arteries and arterioles, thrombosis of hilar and arcuate arteries. Platelet aggregates and fibrin thrombi in glomerular and peritubular capillaries and interstitial hemorrhage [21].

\section{Management of $A V R$}

Once diagnosis of AVR was established. cases were initially treated by methyl predinsolone $(500 \mathrm{mg}$, intravenous for 5 consecutive days). In 9 cases this was the only modality used. In 5 cases, additional plasma-exchange was neede.

Cases with unfavourable response to steroids received additional therapies as ATG or MAB. These were given for 25 patients. Ninetecn patient out of them required additional plasma exchange as well.

ATG (Fresinius, FDG) was given at a dose of 3-5 $\mathrm{mg} / \mathrm{kg} /$ day as 4 hours slow infusion for 10-14 days. Alternatively $\mathrm{OKT}_{3}$ (monoclonal $\mathrm{AB}$ ) was given as an intravenous bolus of $5 \mathrm{mg}$ daily for 10 days. Plasma exchange was carried out on alternate days for 5 sessions. Cyclosporin was witheld, to be reintroduced on the $8^{\text {th }}$ day of therapy.

A successful response to $\mathrm{ATG}, \mathrm{OKT}_{3} \pm$ plasma exchange was defined as improvement in serum creatinine level or return to prerejection values with improvement of clinical and biological parameters of acute rejection.

\section{Statistical analysis}

Statistical analysis was carried out using SPSS package. For uni-variate analysis, student $\mathrm{T}$ test, Chisquare test were used. Multivariate analysis was carried out using COX logistic regression. Graft survival was computed using Kaplan-Meicr method [22]. Differences werc compared using log rank test.

\section{Results}

Patients demographics data arc shown in table 1 There was no significant difference, regarding age. sex of the donors or recipients, between patients who developed acute vascular rejection (AVR) and thosc who did not.

The original kidney diseases are summarized in table 2. There was a statistically significant difference between the above groups on univariate analysis $(p<$ 0.04).

The immunological variables are summarized in table 3. Out of these variables, threc factors showed statistically significant difference namely: donorl recipient consanguinity, pretransplant blood transfusion, number of grafts received.

AVR was significantly higher in patients who received their grafts from unrelated donors and in retransplanted patients whereas lower incidence was found in patients who received blood transfusion prior to transplantation, however the number of transfusion reccived did not have an impact.

The initial immunosupression regimens as well as the number of acutc rejection episodes encountered are outlined in table 4. The initial immunosupression did not have an impact on the incidence of $A \vee R$, morcover it could be observed that the frequency of acute rejection and eventual development of chronic rejection was higher significantly in patients who developed AVR (table 4,5). 
The multivariatc analysis (table 6) indicated that only three factors act independently namely prior hlood transfusion, donor-recipient consanguinity and retransplantation. So, unrelated transplantation, retransplantation were found to predispose to AVR ( $P<0.01,<0.001$ respectively.)

Graft survival among patients who did not developed any rejection, patients with acute cellular rejection and patients with acute vascular rejection is illustrated in figure 1. Differences are statitically significant $(P<0.001)$. Patients who did not have rejection have 5 years graft survival of $83.27 \% \pm 2.41$ and patients who develop acute cellular rejection had survival of $71.78 \% \pm 2.04$ whereas patients with AVR have survival of $30.88 \% \pm 9.23$ at 5 years.

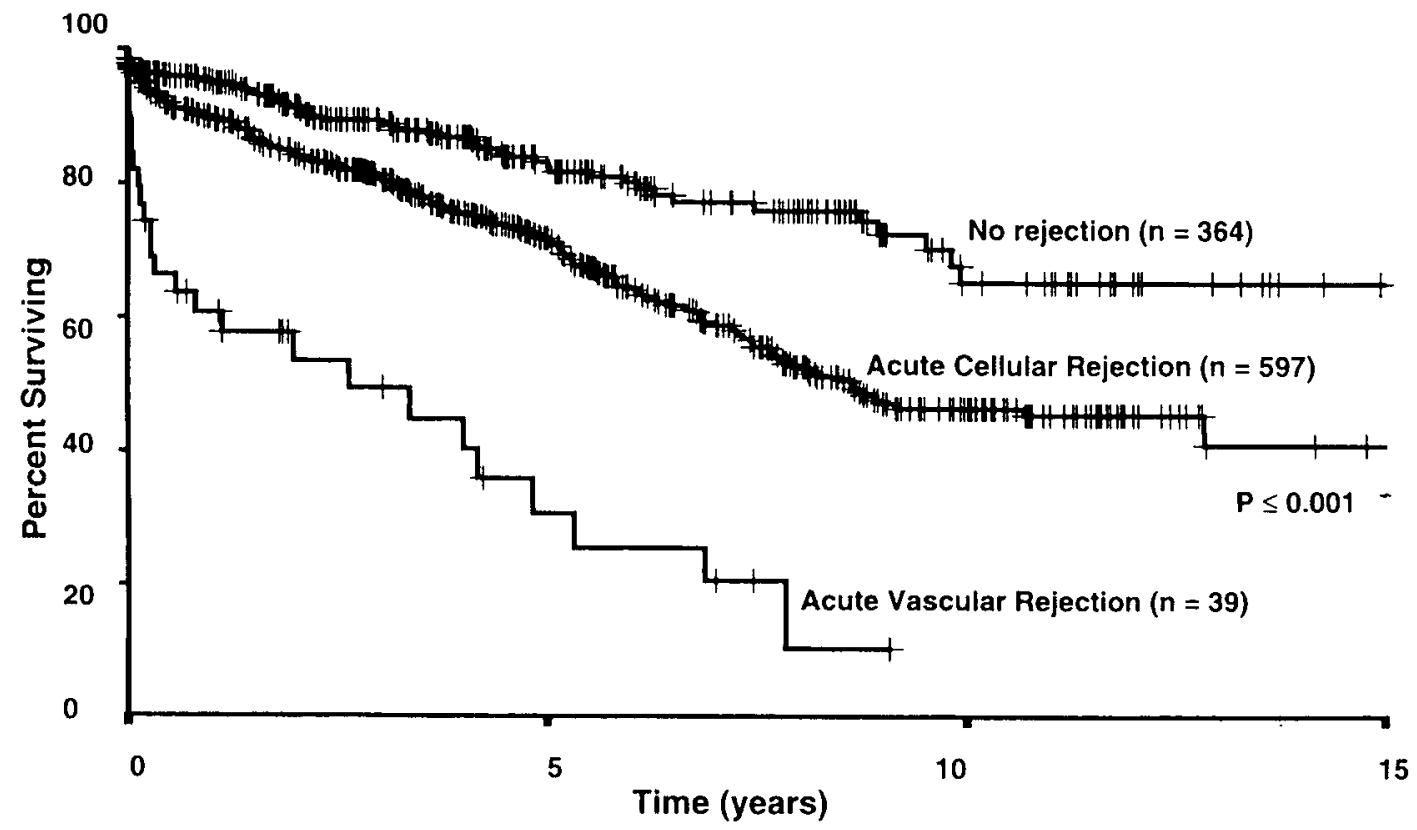

lig. I. Kaplan-Mcier curves for graft survival of patients who developed acute vascular rejection compared to patients who had acute cellulat rejection and to paticnts who did not experience acule rejeclion crises.

Gralt survival at 2.5 ycars post - transplantation were correlated with treatment modalities adopted. No clcar advantage of any specilic regimen is evident $(P>0.05)$ (table 7$)$.

At last follow up, 14 patients $(35.9 \%)$ were living with functioning grafts with a mean scrum creatinine of $1.75 \pm 1.58 \mathrm{mgldl}, 16$ patients (41\%) werc on dialysis due 10 graft failure secondary to chronic rejection or failure of antirejection therapy. Five paticnts $(12.8 \%)$ dicd with functioning grafts due 10 cardiovascular (4 patients), pulmonary complications (onc patient). Four patients died with failed grafts (table 5).

Table 5. Condition at last follow up

Vascalitic gromp $(n o=.39$ patients $)$

Non vasculitic group (no $=96$ Ipatients)

\begin{tabular}{|c|c|c|c|c|}
\hline & no & $\%$ & no & $\%$ \\
\hline living with functioning gralis. & 14 & $(3.5 .9)$ & 690 & $(71.8)$ \\
\hline Living on dialysis & $16^{*}$ & $(41.0)$ & 110 & $(11.4)$ \\
\hline Died with funclioning grafts. & 5 & $(12.8)$ & 82 & $(8.5)$ \\
\hline Dicd with failed grifts. & $4^{*}$ & $(10.3)$ & 79 & $(8.2)$ \\
\hline Probabilitics & & $P \leq$ & & \\
\hline
\end{tabular}

* (irali failure was due to chronic rejection (I I patients) or lach of response to therapy. 
Table 6. Logistic regression analysis of data in vasculitic group

\begin{tabular}{|c|c|c|c|}
\hline Relevant variables & Regression estimate $(B)$ & Standard error $(S E)$ & Probablities \\
\hline \multicolumn{4}{|l|}{ 1- Prior blood transfusion } \\
\hline $\begin{array}{l}\text { Yes } \\
\text { No }\end{array}$ & 0.000 & 0.000 & \\
\hline No & 1.0567 & 0.3459 & 0.002 \\
\hline \multicolumn{4}{|l|}{ 2- Consanguinity } \\
\hline $\begin{array}{l}\text { Related } \\
\text { Unrelated }\end{array}$ & 0.000 & 0.000 & \\
\hline $\begin{array}{c}\text { Unrelated } \\
\text { 3- Transplant received }\end{array}$ & 1.840 & 0.3483 & 0.015 \\
\hline \multicolumn{4}{|l|}{ 3- Transplant received } \\
\hline $1^{\text {st }}$ graft & $\begin{array}{l}0.000 \\
1.7009\end{array}$ & $\begin{array}{l}0.000 \\
0.5127\end{array}$ & 0.0009 \\
\hline $2^{\text {nd }}$ graft & & & \\
\hline
\end{tabular}

Table 7. Impact of adjuvant drug therapies on graft survival

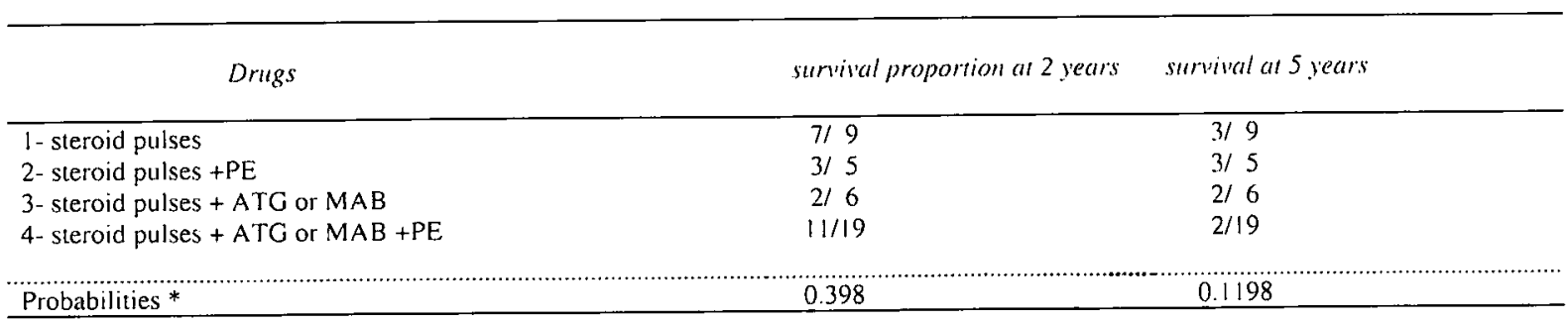

* Significant at $\mathrm{P} \leq 0.05$

\section{Discussion}

Acute vascular rejection (AVR) as an early complication of renal transplantation is not usually amenable to conventional antirejection therapy. The question has been raised as to whether in grafts with severe rejection, treatment should even be attempted. Few randomized studies were conducted on this subject $[1,23]$.

In the present study, 39 patients with severe AVR were studied. The criteria of diagnosis and stratification of AVR were as described by Solez et al., 1993 [21]. It was shown that dividing rejection into either vascular or interstitial had an important prognostic significance on both graft survival and response to therapy [3].

In our work, the overali survival analysis of patients with AVR showed statistically significant reduction of graft survival compared to patients with acute cellular rejection (ACR) and to patients who didn't develop post-transplantation acute rejection $(\mathrm{P}<0.001)$. This confirms previously published reports by other investigators, who had also found that early vascular rejection after K. $T_{X}$ is strongly related to development of chronic rejection and graft loss at 2,5 years after K.Tx [3,24,25].

Although some possible risk factors for vascular rejection were identified, the pathogenesis of AVR is not well understood. Humoral immunity may be of major importance in the pathogenesis of vascular rejection after K.Tx. Three endothelial - associated antigen systems are known against which antibodies can be directed. The oldest known system that is associated with rejection is the HLA system. A second system was identified in patients with AVR by detection of antibodies against endothelial cells and monocytes. Reccntly, a third system with allospecific antibodies against human umbilical vein endothelial cells was demonstrated and was associated with both occurrence of AVR and poor graft survival. These data suggest that in AVR, alloantibodies may be present and directed against a non - HLA polymorphic alloanligen system present on endothelial cells and platelets [3].

The hypothesis that humoral immunity plays a major role in vascular rejection is supported by occasional successful treatment of vascular rejection with polyclonal, monoclonal antibodics $\{26,28\}$ or removal of antibodies by plasma exchangc |3|. It was previously reported that monitoring of antibody derived cell mediated cylotoxicity (ADCC) could predict rejection as carly as 15 days in advance of any clinical or biochemical signs of rejection $[29,30 \mid$. However our own previously published observations did not confirm these conclusions $131 \mid$.

In this study, we attempted to identify the possible risk factors which are associated with increased incidence of AVR. The initial univariate analysis had identified the following factors as significant: original kidney disease, donor - recipient consanguinity, pretransplant blood transfusion and the number of grafts received. Nevertheless, multivariate analysis using COX - regression model had identified the following factors as significant and acting independently namely: Pretransplant blood transfusion, donor - recipient consanguinity and the number of grafts received. So this work suggest that transplantation from unrelated donors, retransplantation significantly increased the incidence of AVR after KTx. On the contrary, prior nonspecific blood transfusion regardless of its frequency, improved graft survival significantly and paticnts 
were less prone to AVR after K.T. These results were approved by other investigators $\mid 3.6,7,321$. although some denied the role of prior blood transfusion $|33|$. It was also noted that patients who had AVR were more prone for repeated acute rejection episodes and eventually the development of higher incidence of chronic rejection.

All patients cnrolled in this study had received steroid pulses initially for the treatment of their AVR. Subsequently in view of lack of response to this therapy different additional modalities were employed: ATG, MAB \pm plasma exchange (PE). We could not clearly identify the superiority of any spccific regimen and a decrease in graft survival at 2.5 years was found. It must be noted that in recent data $[5,34,35]$, utilization of Tacrolimus was reported as a potent agent which can reverse AVR in $65 \%$ of cases.

In this work, the 5 years graft survival in patients with AVR was $30.8 \%$. This reflects a poor prognosis of AVR. Our rcsults did not support other reports illustrating the beneficial effect of ATG/ or $M A B$ on the outcomc of AVR [26,27].

So, on the basis of the study of the potential risk factors, it is clcarly cvident that such patients who are more prone for AVR should receive initially more potent immunosuppression. Furthurmore ATG or MAB should be administered prophylactically rather than salvage therapy.

\section{References}

I. Salmella KT, Von-willebrand IEO, Kyllônen LEJ, Eklund BII, lôchersede KAV. Ksoniemi HM. Krogerus 1. Taskinen E and Ahonen PJ: Acule valscular rejection in renal Ianuplantalion - Diagnosis and Outcome. Transplantation 1992: $54: 858-862$

2. Delancy Vb, Camphell WG, Nasr SA. Mc Cuc PA, Warshaw B, and Whelchel J1): Ellicacy of OKT 3 monoctonal antibody therapy in steroid resistant, predominantly vascular acute rejection. A report of 3 cases with morphologic and immunophenotypic evaluation. Transplantalion 1988; 45 (4): $743-748$

3. Valn Salase JI.CM. Van Der Woude FJ. Thorogood J. Ilollander $A M J$, van IES LA, Weening JJ, V.Bockel Jll and Bruign JA: The relation belween acure vascular and inlersticial renal allogralt rejection and subsequent chronic rejection. Transplantation 1995: 59 (9): 1280-1285.

1. Tallabe K, Takahashi K, Toma H: Causes of long $1 \mathrm{erm}$ grali fallure in renal fransplantation. World J Urol 1996: 14: 2302.35

5. Jordan ML. Shapiro R, Vivas $\Lambda$. Scantlebury II, Gristsch IIA, Ellis D, Gilboa $N$ and stard TL: The use of tacrolimus in renal Iransplantation. World J Urol 1996; 14: 239-242

6. Sever MS, Eeder T. Aydin E. Türkmen A. Kihiçaslan I. Uysal $V$, liaksoy 11 , falangu $S$, Carin $M$, Eldeger $U$ : Living unrelaled (Paid) Kidney transplantation in third-world countries: NDT 1994; 9: 350-354.

7. Colakoglu M, Akpolat T, Arik N, Uias C, Arinoy T, Sindel S, Sungur $C$, Yasuvul ü. Turgan $C$ and Caglar $S$ : Oulcome of renal transplantalion from forcign unrelated living donors in Turkey. Nephron 1995:71: 244-245

8. Schroeder TJ, Weiss MA, Smith RD, stephens GW, Firsı MR: The efficacy of $\mathrm{OKT}_{3}$ in vascular rejection. Transplantation $1991: 51(2): 312-315$
9. Cosimi $\mathrm{AB}$ : Antilymphocyte globulin and monoclonal antibodies. In "Morris PJ" (ed) kidney transplantation.

principles and practice. $3^{\text {rd }}$ ed. 1988: Saunders, Philadelphia PP 343-369.

10. Cosimi AB: Antilymphoctye globulin - a final (?) look. In Morris PJ. Timey NL (eds) : Progress in transplantation. Churchill livingstone. Edinburg 1985: PP 167-188.

11. Matas AJ. Tellis VA. Quinn T. Glichlick D. Soberman R, Weiss R. Karwa $G$ and Veith FJ : ALG treatment of steroid- resistant rejection in patients recciving cyclosporine. transplantation $1986 ; 41(5): 579-582$

12. Tesi RJ, Elkhammas EA. Henry ML and Ferguson RM: $\mathrm{OKT}_{3}$ for primary therapy of the first rejection episode in kidney transplants. Transplantation 1993; 55,1023-1029.

13. Norman DJ. Barry JM. Funnell B. Henell K. and Goldstein G: $\mathrm{OKT}_{3}$ for treatment of acute and steroid and ATG - resistant acute rejection in renal allograft transplantation. Transplantation proceedings 1985; XVII (6), PP 2744 -2747

14. Jagose JT. Bailey RR. Lym KL. Robson RA and Wells JE: $\mathrm{OKT}_{3}$ for treatment of steroid - resistant acute renal allograft rejection. Nephron 1997: 77: 298-303

15. Langley J. Vergne - Marini P, Dickerman R. Long D. Nesser, D. and Veles $R$ : Treatment of renal allograft rejection by plasmaphcresis. transplantation proceedings 1985, XVII (6). $2773-2776$.

16. Eismann - R. Konen -J. Langkopf $B$ : Experiences with plasmaphresis in the treatment of vasculat rejection following kidney transplantation. Z Urol-Nephrol 1990:83 (1):9-12

17. Fassbinder, W. Scheuermann E.H. Hanke P.B. Bechstein. W. Enst, Slulte $\mathrm{HJ}$ and Schoeppe W: Improved graft prognosis by treatment of steroid resistant rejections with rabbit Amithymocyte globulin and/or plasmapheresis. Transplantation Proccedings 1985: XVII: 2769-2772.

18. Haberal M., Bulut O. Surt S. , Glay H., Arslan Gngen Y. hamaloglu E. Altunkan S. . Bilgin N. : Treatment of steroid resistant renal allograft rejection with $\mathrm{OKT}_{3}$ and plasmapheresis. Ren Fail 1991:13 (1), 43-47

19. Ghoncim MA. Sobh MA, Shokeir AA. Bakr A. El sherif A and Foda MA: Prospective randomized study of tripple $V_{3}$ conventional immunosuppression in living donor kidne) Iransplantation. Transplantation Procceding 1993: 25 (3). P 2243-2245.

20. Ghoncim MA. Sobh MA, Shokeir AA. Bakr MA. El sherif A and Foda MA: Prospeclive randomiced study of Azathioprine versus cyclosporinc in live-donor kidney uansplantation. Am.J Nephrol, 1993; 13: 347-441.

21. Soley K, Axelsen RA. Benediktsson H: International standariation of criteria for the histologic diagnosis of renal allograft rejection: The Banff working classification of kidney transplant pathology. Kid. Int. 1993: 44: $411-422$

22. Kaplan EL. Mcicr P: Non parametric estimation from incomplele obscrvations. J Am Stat Assoc 1958: 53: 457-481.

23. Gilabert R. Campistol JM, Bru C. Vilardell J. Bianchi L, Andreu J: Utility of pulsed Doppler in the diagnosis and follow-up of acute vascular graft rejection treated with $\mathrm{OKT}_{3}$ monoclonal antibody or antilymphocyte serum. Transplantation 1991; 51:614-618

24. Almond PS, Matas A, Gillingham JS, Dunn DL. Paryne WD. Gores $P$, Gruessner $R$, najarian IS: Risk factors for chronic rejection in renal allograft recipients. Transplantation 1993; 55 752-757.

25. Basadonna GP, Matas AJ. Gillingham KJ: Early versus late acutc renal allograft rejection: impact on chronic rejection. Transplantation 1993; 55; 993 - 995.

26. Cosimi AB: Antilymphocyte globulin and monoclonal antibodies. In: Morris PJ (ed) kidney transplantation. Principles and praclice, $3^{\text {rd }}$ edn Saunders Philadelphia 1988: P 343-369.

27. Richardson AJ, Higgins RM, Liddington $M$, Murie J, Ting A and Morris PJ: Antithymocyte globulin for steroid resistan rejcction in renal transplant recipients immunosuppressed with tripple therapy. Transplant Int. 1989; 2: 27-32. 
28. Petrie JJ. Rigby RJ, Hawley CM, Suranyi MG. Whitby M. Wall D and Hardie IR: Effect of OKT3 in steroid-resistant renal transplant rejection. Transplantation 1995; 59 (3): 347 . 352.

29. Yard B, Spruyl-Cerritse M, Claas F. Thorogood J. Bruizn JA, Paape ME, Stein SY, Van ESLA, Van Bockel JH. Kooymans-Coutinho $M$, Daha MR and Van Der Woude FJ: The clinical significance of allospecific antibodies against endothelial cells detected with an antibody-dependent cellutar cytotoxicity assay for vascular rejection and graft loss after renal Transplantation. Transplantation 1993:55 (6): 1287-1293

30. Attallah AM, Abdelghaffar H, Fawzy A. Alghraoui F., Aligani MR, Ghoneim MA and helfrich G.B.: Early immunological prediction of renal allograft rejection. Int arch allerg appl immunol 1987: 83: $83-87$.
31. Bakr MA. Moustafa A. El diasty T. Moustafa F. Ghoneim MA: Post-renal transplant monitoring: The value of biological assays. Transpl. Proc. 1997: 29: 1778-2780.

32. Terasaki. PI, Himaya NS. Cecka M, Cicciarelli J. Cook DJ, Ito T. Iwaki Y. Mickey MR, Takiff H. Tiwari JL and Toyotome A. In "Clinical transplants" (PI Terasaki. Ed.) UCLA Tissue typing Laboratory. Los Angeles 1986. $367-392$.

33. Oplez G., for the collaborative transplant study: Improved kidney graft survival in non transfused recipients. Transplant. Proc. 1987: 19: 149-152

34. Jordan ML. Shapiro R, Vivas A. Scantlebury VP. Rhandhawa P. Carrieri G. Mc Cauley J. Demetris AJ. T/akis A, Fung JJ. Starıl TE: FK 506 "rescue" for resistant rejection of renal allografis under primary cyclosporine immunosuppression. Transplantation 1994; 57: 860-865.

35. Mathew A, Talbot D. Minford EJ: Reversal of steroid-resistant in renal allograft recipients using FK 506. Transplantation 1995; 60(10): $1182-1184$. 


\section{FRENCH ABSTRACTS}

1. Allèles HLA-DRB I chez les enfants avec glomérulonéphrite post-streptococcale aiguë.

II. Le virus de l'hépatite $C$ comme facteur étiologi(que éventuel du sỵndrôme néphrotique idiopathique chez les patients ćgyptiens.

III. Etude des formes cliniques de L'hypertension arterielle dans un service d'urgences medicales à Alidijan.

IV. Réutilisation du dialyseur, effet sur l'éfficacité et la biocompatibilité.

V. La lipoprotéine (a) chez les tranplantés: Un cas d'étude clinique prospective contrôltéc.

VI. Taux de zinc plasmatiques et intracellulaires (plaquettes) chez les patients en insuffisance rénale chronique (IRC) traités de différentes façons.

VII. Contrôle de l'hyperphosphatémie des patients sous hémodialysse régulière (HDx) par acétate de calcium (AC) versus carbonate de calcium (CC). Une étude prospective en double arcugle croiséc.

VII. Réjet vasculaire aigu après transplantation rénale, évolution et résultats de différentes therapics. 


\section{Allèles HLA-DRB 1 chez les enfants avec glomérulonéphrite post-streptococcale aiguë}

Résumé: Pour ćludier l'association des allèles HLA-DRBI ct de la glomćnulonćphritc aiguë posı streptococcalle (GNAPS). 32 cufints alvec GNAPS et 380) sujets sains de la même région ont ćté testé pour les allè̀les DRBI cu utilisant la mćlhode de polymćrisation de chaine hybridation rérerse.

Les patients ayant une GNAPS araicnt une fréquence accruc des deux DRB $1 * 0.3011$ (46.9 vs. 19.2\% che\% les contrôles. $p=0.0(0) 25)$ el DRBI*1 $10.5(31.1$ is. $15.6 \%$ clice les contrölcs. $p=0.01097)$. Cepcndant apres correclion des valleurs de $p$ scule la différence pour DRB1*0.3011 resic significaltive $(p c=0.02 .5)$. Leurs risques relatifs sont significativenent élerés 13.71. intenale de confiance (IC) $=1.8-7.8$ el 3.57 . (IC) $=1.4-8.9$ respectivementf. II n'y avait pas de différence entre les fréquences des deux allèles che\% Ies patients cl les degrés d'hypertension. protcinuric el hématuric.

Conclusion: Les allèles DRBI*(0)3011 et ćrentucllement 1105 confèrent unc susceptibilité à la GNAPS mais la gravité de la maladic n'est pas determince par ces deux allèles.

\section{Le virus de l'hépatite $\mathrm{C}$ comme facteur étiologique éventuel du syndrôme néphrotique idiopathique che\% les patients égyptiens}

Résumé: L'infection par le vinus de l'hépatite $\mathrm{C}(\mathrm{HCV})$ est associćc a une varićté de manifestations cxtrahépaltiques. parmi lesquelles la croglobulinémic et la glomérulonéphrite. Lil glomérulonéphrite du vinus de l'hépatitc $\mathrm{C}(\mathrm{HCV})$ pourait constituer une maladic gloménulairc primairc.

Notre étude porte sur 50) paticnts adultes égypticns diagnostiqués comme ayant un sýndröme néphırotique idiopathique (SN). Nous anons decrit les caractéristiques cliniques. pathologiques ct immunologiques de ces palticnts. Une préallence importante d'infection à HCV a ćé retrouvéc cher ces paltients $(50 \%)$. Les facteurs de risque ćtudićs ont ćtc la transfusion sanguine $(16 \%)$. unc intervention chirurgicalc $(2+\%)$ et un traitement antibilharzicn (76\%). Une hépatomćgalic a ćté observée dans $24 \%$ des cas

Le 1ype pathologique le plus fréquemuncit associćc à l'HCV a ćić la gloménulonćphrite membranoproliférative (MPGN) ( $48 \%$ ). Les autres types ćtaicnt la gloménulosclérose focale el segmentale (FSGS) dans $32 \%$ des cas. la glomerulopalhic cxtramembrancuse dans $8 \%$ el la nćphrose lipoidique dans $12 \%$. Les cryoglobulines ont éc délectécs clice. $5.6 \%$ des 18 particuts arec HCV et SN idiopathique.

Les paticuls ayant unc infection à HCV et une glomérulonéphrite membranoproliférative avaicul une ly pocomplémentémic et des anticorps anti-nucléaires dans $+1.6 \%$ des cas.

En vue de l'cicultuclle association de l'infection à HCV ct de différentes gloménulopanthics. un dépislage de routine du $\mathrm{HCV}$ doit ćtre pris cn considération che» ces paticnts. Cependant unc ćtude séroćpidémiologique étenduc à un nombre plus important de paticnts est nécessairc pour déterminer une ćcentucle relittion aree une infection par $\mathrm{HCV}$.

\section{Etude des formes cliniques de L'hypertension arterielle dans un service d'urgences medicales a Abidjan}

Résumé: Les autcurs ćludicnt les formes clinique de l'lyypertension antericlle et le rôlc aggravant des chiffres Icnsiomels supcricurs à $240 \mathrm{~mm}$ de $\mathrm{Hg}$ pour la systolique et 1+() $\mathrm{mmHg}$ pour la diastolique appelćcs Supcrhypertensions artérielles clic $2.30($ adultes Noirs Africans admis dans le service des urgences médicales à Abidjan.

L'hyperiension artériclle qui représente $8.27 \%$ des adinissions constituc la principale caluse de mortalité dans ce serice $(12.9 \%$ Versus $7.2 \%$ pour les autres affections).

Les complications suivantes ont été notécs: insuffisance cardiaque (29\%). accident vasculaire cérébral (21\%). cncéphalopathic (19\%). insuffisantec rénale (16\%). L'association diabètc. hypertension artériclle cs1 notćc diuls $8.3 .3 \%$ des cals. Une mortalité élcréce est obscrvée cn cas d'acciden vasculaire cérébral $(25 .+\%)$ et d'insuffisantece rénalc (25\%). Le taux de montiaté est fortement lić à l'importance des chiffres tensionucls. 


\section{Réutilisation du dialyseur, effet sur l'éfficacité et la biocompatibilité}

Résume: Quize paticnts sur hémodialyse de maintien ont ćté étudićs alant et aprés réutilisation des diallscurs a ribres creuses cu cuprophane pour évaluer la biocompatibilité et l'cfficacitć du dialỵscur.

Il y a cu unc alugmentation statistiquement probante de l'hématocrite et du taux d'lémoglobine à la fin de la dialysc. Une diminution significatice des lencocrtes totaux (ncutrophiles. cosinophiles) et des plaquettes avec IIII pic a 15 minutes après le début de lil dialysc. puis une augmentation progressive jusqu'a la fin de la dialysc où ils ont altcint les valcurs de pré dialyse.

Ces changements ont cu licu à la première utilisation et au cours des sessions de réutilisation. La diminution des ncutrophiles ćtait moindre ar'ce les dialyscurs réutilisés qu'avec les dialyseurs utilisćs pour la première fois. Le complément terminal dı complexe (CTC) ćait augmenté de manière probante et a atteint un maximum après 15 minutes puis il a diminuć jusqu'à la fin de la dialyse. Ces changements étaient statistiquement moindres a la réutilisation quau premier usage. Il n'y arait pas de relation entre l'altération du CTC et la dimimution des différents éléments cellulaires. II y arait unc angmentation du bicarbonate plasmatique el du pH i) la fin de la dialyse. Une hypoxic et lyypocapnic ont cu licu peu après le début de la session de dialyse arec dialysill ì acćlatc. mais clles sont revenues aux valcurs pré dialysse à la fin des deux sessions. Celà peut être alltribuć à la perte de dioxide de carbone dans le dialysat avec hypoventilation subséquente.

La cléarence de l'uréc. de la créitinine el du phosphore ont montré unc légère différence entre la première utilisation et la réutilisation i 0 et the avec dimmution significative a la fin de la dialyse dans les deur cals. Ceci peut čtre dî au faiı que l'aire de surface du dialỵscur réutilisć a ćté maintenue dans des limites acceptables (80)-10(0) par rapport au dialyscur de premicr usage.

Le dialyscur réutilisć ćtail en quclque sorte plus hémocompatible que celui de premier usage. l'activation du complément ne semble pas ĉtre le seul factcur responsable des réactions de biocompatibılitć durant la dialısc. La dialyse awec réutilisation pent ére une méthode sürc. quand unc stérilisation approprićc. un stockage adćquilt ct unt nombre limitć de réutilisations ont ćıć adoptés.

\section{La lipoprotéine (a) chez les tranplantés: Un cas d'étude clinique prospective contrôllée}

Résumé: Cclte ćtude a ćé concuc pour ćvalucr l'impact de la transplantation rénale (TX) sur le profile des lipides des palients en insuffisance rénale chronique (IRC). Elle comprend trente sujets nomaux (N) de contrôle cl cent cals d'IRC Iraités par TX et répartis sur trois groupes.

Groupc I: Dix patticıts cu IRC rus au cours du bilan prćopératoirc el suivis à un cl six mois post TX.

Groupc II: Trente palıcnts TX suivis cu période post-opératoire sur un an.

Groupc III: Soivantle transplantés. cximinćs justc après une TX réussic.

Les pilramètres suivalnts ont été mesurés el suivis sclon te plan de chaque groupe: Taux sérique de Lp(i)). cholestérol total (CT). Irigh cérides (TG). HDL. LDL. protéincs totales (PT). albuminc (Alb) el créatininc. Une Elude Duplex des arières carotides a été faite el suivic sur un an che\% dix paticnts du groupe II choisis ilćilloirement.

Les taux sćriques de $L p(i)$ ont dimunué significaltivement au cours des dourc mois de suivi. Ces taux ćlaicut significillirement plus ćlerés a tout moment cn comparaison arec $N(p<0.00() 1$ cn tout).

Outre l'effect filvorable de Tx sur $L p(a)$ clle a cu des effets varbibles sur les autres paramètres des lipides cualués pré ct post opération. Alors qu'une dimimution des TG a ćć observéc $(p<0.001)$. il y a cu augmentation dı CT $\left(p^{-}(0.0(0))\right.$. HDL $(p-0.005)$ ct LDL $(p<(0.0) 1)$. Il n'y a pas cu de corrćlation significative entre Lp(ia) d'unc part el d'autre part l'age. Ie serc. la créatinémic. PT. Alb ou les autre paramètres des lipides amalysés daus les direrses groupes. Aucun des dix paltents cxamininés par Duplex n'il cul un changement dans l'athérosclérose des carrolides sur une annce de suivi.

Conclusion: TX a un efret fiv orable sur la concentration sćrique d'un facteur de risque athérogéne réccmuncut decril. Lp(a). L'abscnce de channgement de l'athérosclérose carotidicnne dans celte ćlude n'cxclus pas le rôle largement admis de l'aclivité athérogène de $L p(a)$. L'absence d'effet de Lp(a) est probablcment duc a l'angmentaltion significative du cholestćrol HDL après TX. 


\title{
Taux de zinc plasmatiques et intracellulaires (plaquettes) chez les patients en insuffisance rénale chronique (IRC) traités de différentes façons
}

\begin{abstract}
Résumé: Les méchantismes el degrés de déficicnce co zinc $(\mathrm{Zn})$ alu cours de l'urémie restenl un suj̣ct de controverse. Les résultats des différents modes de traitements ne sont pas établis. Le Zn plasmatique ne représente qu'une petitc partic du Zn corporel tolal (cnviron (0.5\%). L'ćvaluation du Zn intracellulaire dans les cellules du silng pourait ćtre plus fiable. Cette étude a ćé conçuc pour ćvaluer l'ćlat réel du Zn au cours de l'urćmic el déterminer si les modalités de triatement de l'IRC (conseratrice el dialytiques) pouraicut infuencer l'ćlat du Zn. L'ćtude derail ćgalement ćtudier l'efret d'une session de dialyse. du tỵpe de dialyse el du laumpon du dialysit sur l'ćtal du Zn.
\end{abstract}

Ccıte ćulde comprend dix sujets de contrôle sains el quarante palticuts cu IRC répartis en trois sous-groupes sclon les modalités de traitement différentes 110 traitement consenvatcur. 15 cn dialyse péritonćale intermitenle (DPI) et $15 \mathrm{cn} \mathrm{hémodialysc(HD)|}$

Zn a été mesuré par absorption atomique spectophotométrique du plasma el des plaqueltes

Une diminution statistiquement significative du $Z n$ plasmatique et du $Z n$ des plaquettes a été retrowé cher les paticnts en IRC traités par différents moyens comparés anx contróles $(p-0)(01)$. mais il n'y arait pals de différence notoire cutre les sous-groupes d'urémiques. Il n'y anait pas de différence entre les sous-groupes urémiques el les contrôles quant aux taux des protéines plasmatiques et de l'albuminc. De plus le $Z_{n}$ plasmatique ćlait notoircment augmenté (cependant toujours plus bas que les contrôles) ct le Zn des plaquetıes ćlait noloirement diminuć $(p<0.01)$ après une session de dialyse dans les deux sous-groupes DPI ct HD. mais les différences de ces deux paramètres (avant et après dialyse) étaicnt insignifiantes chez les patients DPI comparćs a HD.

Une relation négative significative a ćté trouvéc entre $\mathrm{Zn}$ des plaquettes el la cléarance de la créatinine dans les trois sous-groupes urćmiques $(r=-(0.81 \quad p<0.01$ che $z$ les paticnt sous traitement conservatcur. $r=-(0.72 p<0 .() 1$ dans DPI et $r=-0.76 \quad p<0.01$ dans HD) mais il n'y avait pas de relation cntre la durce de la dialyse el le $\mathrm{Zn}$ plasmatique on celui des plaquelics. ni entre le $Z n$ plasmatique et le $\mathrm{Zn}$ des plaqueties. la créatinémic el la clćarance. Le Zn plasmatique montrait unc élévation transitoirc notable ches les paticnts HD utilisant un lampon de bicarbonate $(11.6+1.1 \mu \mathrm{mol} / \mathrm{L})$ comparé à ccux utilisant un tampon acétatc $(9.1+1.3 \mu \mathrm{mol} / \mathrm{L})$. $(p<0.01)$.

L'on peut conclure que la mesure du Zn intracellulaire (plaquettes) a une valcur de diagnostic et de monitoring de l'ćtill du Zn clica. Ies urémiques. Les différentes modalités de traitcment u'infuent pas sur l'hémostase du Zı. aucun type de dialyse n'ćlant supéricur sur ce point. L'cffet d'ćlćation du Zn plasmualique après une séamce uniqque de dialyse et l'utilisation d'un tampon bicarbonate versus acćate n'ćail que transitoire cl dii a l'hémoconcentration et à une meilleure correction de l'acidose au cours de la dialyse

Contrôle de l'hyperphosphatémic des patients sous hémodialyse régulière (HDx) par acétate de calcium (AC) versus carbonatte de calcium (CC). Une étude prospective en double aveugle croisée

Résumé: Cclte ćlude comprend quarante paticnts en insuffisance rénale chronique agés de 37 ia 8.3 ans (moyenne 51.3+7) sur HDx trois fois par semaine depuis cntre + et $1+4$ mois $(\mathrm{Kl} / \mathrm{V}>1.2)$. Un dialysat a acćlatc avec unc concentration de calcium de $3 \mathrm{mEq} / \mathrm{L}$ ćtait utilisć. Tous les fixatcurs de phosphate ont ćé intcrrompus pour un mois.

Les paticnts ont étć répartis sur deux groupcs. Groupc I (20 cas) ont reçu du AC alors que Groupe II (20) cas) ont reçu du CC cn doscs equimolaires (10 m. mol de chaque t.i.d.) pour un mois. Un traitcment croisć a ććc fait pour un autre mois cn maintenant les patients sur le méme régime alimentaire.

Les laux de calcium sérique (Ca). calcium ionisć (iCa). Phosphore (P). phosphatasc alkaline (PA). urće (U). créatinine (Cr). ALT. AST. proteines tolales (PT) et albumine (Alb) ont été mesurés au dédut cl à la fin de chaque mois de traitement an $\mathrm{AC}$ et $\mathrm{CC}$.

Le Ca sćrique et iCa ćlaient significativement plus bas dans le groupc I après AC comparés aux taux aprés CC $(p<0.01)$. Des résultats similaircs ont été obsen'és dans le groupc II $(\mathrm{p}<0.05)$

Dans le groupc II scul le $P$ sćrique ćtait significativement plus bas après AC comparés aux laux après CC $(p<0.05)$.

II n'y arail pas de différence notoirc pour PA. U. Cr. ALT. AST. PT. d'cmbléc ce ì la fin de chaque mois de traitcment par $\mathrm{AC}$ ct $\mathrm{CC}(\mathrm{p}>0.05$ pour chaque).

Nous arons cxclu 12.5\% des cas à cause d'unc intolérence au AC. aucun des cas n'a montré d'intolércuce au $\mathrm{CC}$. 
("iml/hsiom!

1) AC n'cst pas meilleur que CC dans le contròle de l'hyperphosphatćmie.

2) AC peut ĉtre augmenté satus risque d'llypercalcémie.

3) La vitaminc $D$ active et un dialỵsat riche cn calcium peuvent être utilisćs pour freiner l'activité parathy roidicnne plus surement arec AC qu'arec CC.

4) Lil tolćrance du CC cst supćricurc.

\section{Réjet vasculaire aigu après transplantation rénale, évolution et résultats de différentes thérapies}

\section{Résumé:}

letere de hase

Le rejet vasculairc aigu (RVA) stéroido-résistant est considéré comme une barric̀re au succès de la tralusplantation rénale (RTX). Cetle élude vise à éludier l'ćvolution des cas de rejets vasculaires aigus prourés histologiquement qui ont en licu de façon aggressive el grave clie . 39 patients après transplantation rénale et ćludier les résultats de la thérapic. Ces cas faisaicut partic de $100($ ) cals de reçeicurs d'allogreffes rémales aul Contre d'Urologie-Nćplırologic. Mansoura. Egypte culre mars 1976 ct avril 1997.

\section{Vétherele}

Une ćlude statistique pousséc des facteurs de risque conduisant au RVA a cée faitc. Les résultats des différentes thérapics utilisćes daus le RVA ainsi que les fonctions du greffon ont été analysés.

\section{Résultati.}

L'ćtude de sunic du greffon avec RVA a été de $60 \%$. 5.3\%. 30\%. $0 \%$ a 1.2 .5 et 10 ans respectivement arec une différence statistiqucment significative $\mathrm{cn}$ comparaison avec les paticnts n'ayant eu qu'un rejet cellulaire aigu $(90 \%$. $84 \% .71 \%$ ct $+6 \%$ de survic du greffon a 1.2 .5 et 10 ans post RT. respectivement) ou ceux n'ayant pas cu de rejul cn période post-1ransplantation (95\%. $91.3 \%$. $83.3 \%$ cl $65.5 \%$ de surie du greffon à 1.2 .5 ct 10 anı respecliicment).

II I': a pils de différence statistique sur la survic du greffon entre les différentes modalités de traitement. Un tratitcment de stéroide par injection + ćchange plasmatique a étć utilisć chez $1+$ patients arce RVA. ATG. MAB + ćchange plismaltique ont ćtć ajoutés aux cas stćroido-résislants ( 25 cas).

L'analyse de régression des domnćes a montré que la transfusion sanguine. une consanguinité domneurreçcreur et unc retransplintation ćtaicm les variables les plus significatives reliécs an RVA aprés transplintalion rénalc.

All dernicr suivi. It paticnts $(35.9 \%)$ sont vivants allec des greffons fonctionnels. 16 palients $(+1 \%)$ sont vivants sous dialysc. 5 paticnts sons décćdés avec des greffons fonctionncls $(12.8 \%)$ ct + paticnts $(10.25 \%)$ sont décćdés arec des grcifons non fonctionnels. Ceci montre bicn l'effet néfaste du RVA sur le devenir du greffon.

En conclusion: Le RVA resie un obstacie majcur pour la RTx car il affecie foriement la survic du greffon cl répond mal a la thérapic. Unc transfusion sanguinc pre transplantation diminuc l'incidence de RVA alors que li) retrilusplantation el le don d'organcs non relićs contribuents de manière significative au RVA post RTx. 